\title{
Letter
}

\section{New languages for the spreading of scientific knowledge: broadening the dialog between science and society}

\author{
Danielle Pereira Cavalcanti, Cecília C. B. Cavalcanti
}

\begin{abstract}
The Internet is by far the most intensely used communication tool of today and the main channel of interaction in the globalized world. This technology has opened up a whole new area for the interaction of knowledge: cyberspace, where information is always present and continuously changing. The interactivity that characterizes the virtual media together with the interactive modules developed by science centers and museums make the Internet a whole new space for the popularization of science. In order to stimulate dialog between science and society, Espaço Ciência Viva has decided to employ the Internet to divulge and to popularize scientific knowledge by bringing debates about the advances of science to the daily lives of people. To this end, its website was remodeled, which led to an increase of up to $600 \%$ in the number of visitors.
\end{abstract}

\section{Theoretical background}

In the social context in which we live, where technology is evermore present in the lives of individuals and the access to information becomes a determining element of individual, social or corporate success, we can highlight the role of new information and communication technologies as the main driving and sustaining forces of current society. Because of its characteristics, services and potentialities, the World Wide Web surfaces as an important resource in favor of society, given its capacity to store and disseminate large quantities of information without geographic limits or time barriers. ${ }^{1}$ The Internet was first developed because of questions related to war security. Later on, it was used in conjunction with universities in order to resolve problems in the area of scientific research. However, it has expanded in such a way that it has become one of the most important means of communication today. The Internet has not only become the most well-known and most widely-used instrument of interaction in our globalized world, causing information to no longer be an area or a specialization. It has also gone on to become a dimension which deeply transforms the way in which society organizes itself. ${ }^{2}$ As technology advances, information is transmitted faster and faster, reaching satellite transmissions in a short period of time and culminating in the typical on-line format of the Internet. The educational system and social communications have undergone a series of changes because of technological advances and their consequent repercussions in the political, social and economic fields. As education philosopher Jorge Larrosa $^{3}$ points out, social and individual relations already reveal changes that have arisen with regard to attitudes and the way of thinking of this new world view. New technologies have generated a new space of knowledge - cyberspace, which is everywhere, in all times, and where information is ever-present and constantly being renewed.

In the "Information Era", where everyone lives in a constant state of unrest in search of knowledge, science centers and museums have come to take on a new social role. They have arisen as alternative spaces for the transmission of information and science education. Through these spaces, education and science communication have begun to use a new language that includes interactivity and technology in exhibits and activities as a methodology that is able to engage the visitor in a process called hands-on, minds-on and hearts-on. ${ }^{4}$ Given that the interactive nature of a virtual setting can be joined together with the experimentation of interactive modules developed by current science centers and museums, we can think of the Internet as a new space for scientific communication that has been elaborated by these centers, thus creating a new relationship with the visitor/user-mouse-on. In this study, we report the 
experience of remodeling the website of Espaço Ciência Viva (ECV, which translates into English as "Live Science Space"), the first interactive science museum created in Brazil. This remodeling fostered a transition from a strictly institutional editorial perspective to a differentiated editorial perspective that values and produces exclusive scientific content. The current objective of the ECV site is to make use of the benefits brought about by the World Wide Web in order to spread and communicate scientific knowledge, thus democratizing access to knowledge and placing science within the everyday lives of individuals.

\section{Justification and methodology}

Science centers and museums provide a great public service that traditionally takes place inside of their facilities and during determined hours of operation. However, these obstacles often prohibit the public from taking full advantage of the different options of activities during their visit. Technology currently available allows for overcoming barriers of time and space, with the objective of efficiently reaching an ever greater number of people. ${ }^{5}$ The Internet thus becomes a powerful tool in establishing the connection between science centers and visitors, who can access the resources of these spaces from different locations and at times convenient to them. Because of these observations, Espaço Ciência Viva proposed to, through its website, use the World Wide Web to extend its activities in the area of education and science communication. In order to do this, the project Ciência Viva Virtual (meaning "Virtual Live Science" in English) was elaborated. This project consisted of remodeling the ECV site and putting a differentiated editorial perspective into practice. ${ }^{6}$ The Espaço Ciência Viva site (www.cienciaviva.org.br) was first launched in 1999 and had graphic designs in MS-Word and an institutional editorial perspective. At the end of 2004, the site underwent studies for its editorial and graphic modification and had the main objective of being a space for information on scientific activities, debates, news, training, knowledge and art. The new Espaço Ciência Viva website was constructed with the use of HTML, style sheets and some scripts written in JavaScript that were inserted directly into the HTML code. These resources are compatible with a good number of navigator softwares. ${ }^{7}$ The site was organized through a division into sections in order to facilitate access to specific contents and other relevant information about the museum and its events (Table 1). In the "Science in Debate" section, the major current scientific topics are dealt with through texts, interviews with specialists and selected interesting links. The objective of this section is to deal with scientific topics that appear in the media in a way that meets the public's demand for more in-depth and trustworthy content. In order to do this, a multidisciplinary team made up of journalists, scientists and web designers works together to develop this exclusive material. Each time the section is updated, an informational bulletin - also constructed in HTML - is sent to a mailing list, which currently has more than 5,000 e-mail addresses. Any other important updates that are made to the site, such as news items and event coverage, are also sent through the bulletin.

As a way of measuring if the ECV site was sought out more by the public after being remodeled, we analyzed the site's use statistics. The number of visitors - i.e., the number of times a visitor accessed the ECV website - was evaluated periodically in 2005, 2006 and 2007 and the data was plotted on a graph. 


\begin{tabular}{|l|l|}
\hline \multicolumn{1}{|c|}{ Sections } & \multicolumn{1}{c|}{ Content } \\
\hline I-Science in Debate & $\begin{array}{l}\text { Exclusive content, with scientific topics dealt with by specialists and } \\
\text { journalistic coverage of the country's main science communication } \\
\text { events. }\end{array}$ \\
\hline II - Do it yourself & The museum's science modules are taken to virtual interactivity. \\
\hline III- Archive & $\begin{array}{l}\text { Reports, interviews and other topics previously dealt with in the } \\
\text { "Science in Debate" section. }\end{array}$ \\
\hline IV - Friends & $\begin{array}{l}\text { Open space for those who want to participate in activities related to } \\
\text { the museum's science communication and education. }\end{array}$ \\
\hline V- Photo Gallery & $\begin{array}{l}\text { Photos of the activities developed in the museum during the National } \\
\text { Science and Technology Week and other events. }\end{array}$ \\
\hline VI - Astronomy & Astronomy content and activities from the ECV astronomy group. \\
\hline VII - Calendar & $\begin{array}{l}\text { Network of information about the scientific activities sponsored by } \\
\text { the museum, teaching and research institutions and other science } \\
\text { centers. }\end{array}$ \\
\hline VIII - Institutional & $\begin{array}{l}\text { General information about the museum, such as "Who are we", } \\
\text { "Location", "Activities" and the institution's history. }\end{array}$ \\
\hline
\end{tabular}

Table 1. Structural Organization of the Espaço Ciência Viva website.

\section{Results}

The Espaço Ciência Viva website was first launched in 1999 in an amateur fashion (Figure 1), with updates rarely being made and receiving an average of 30 visits per month. In September of 2004, the first graphic modification took place, but the site continued to be institutional in nature, containing only information about the museum's activities (Figure 2). One year later, Espaço Ciência Viva began remodeling its facilities and its interactive modules and the page on the Internet underwent new studies. After detecting that most science centers and museums, including Espaço Ciência Viva, had sites that were strictly institutional in nature, the Ciencia Viva Virtual multidisciplinary team set out to plan a project for the ECV website. It would be constructed with a differentiated editorial perspective that valued exclusive scientific content and dealt with topics of general interest in the fields of astronomy, physical science and biological science. Among the matters dealt with in the site, we highlight topics such as "Dengue fever", "Global warming", "Nanotechnology", "Sexuality", "Astronomy", "DNA", "Stem cells", "Bioethics" and "Biofuels".

The website underwent new graphic remodeling in order to create a visual identity in keeping with the museum's modules, and it was re-launched in December of 2005 (Figure 3). In this new phase, journalistic coverage of important events in the areas of popularizing and communicating science gained priority and, between 2005 and 2007, we covered important events such as "IV World Congress of Science Centers and Museums", I and II National Science and Technology Week, " $58^{\text {th }}$ and $59^{\text {th }}$ Annual Meeting of the Brazilian Society for the Progress of Science (SBPC)", "34 "Conference of the International Committee of Science and Technology Museums - CIMUSET", "XIV International Seminar of Museums, Science and Technology", among others. 


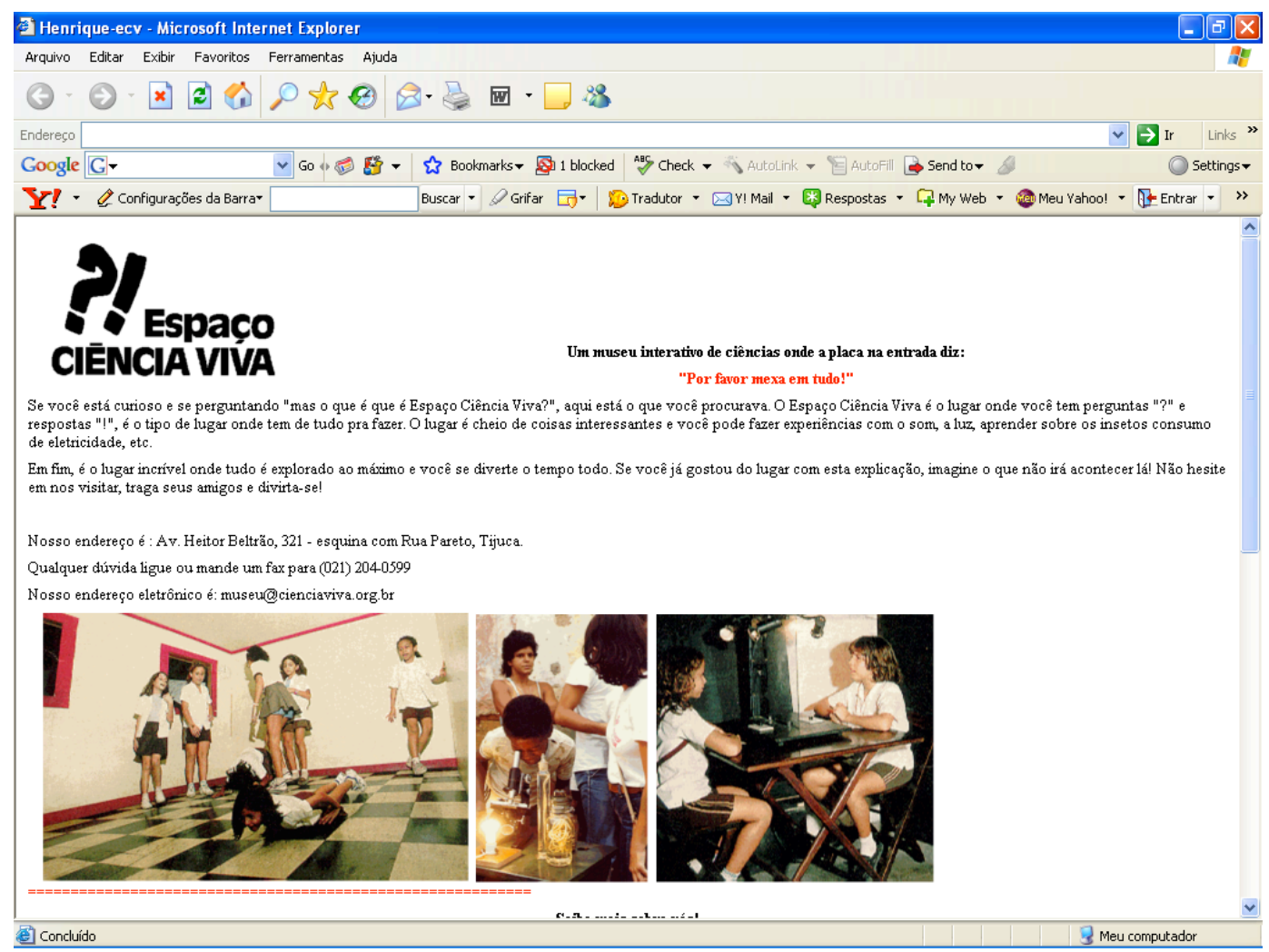

Figure 1. The Espaço Ciência Viva website as launched in 1999.

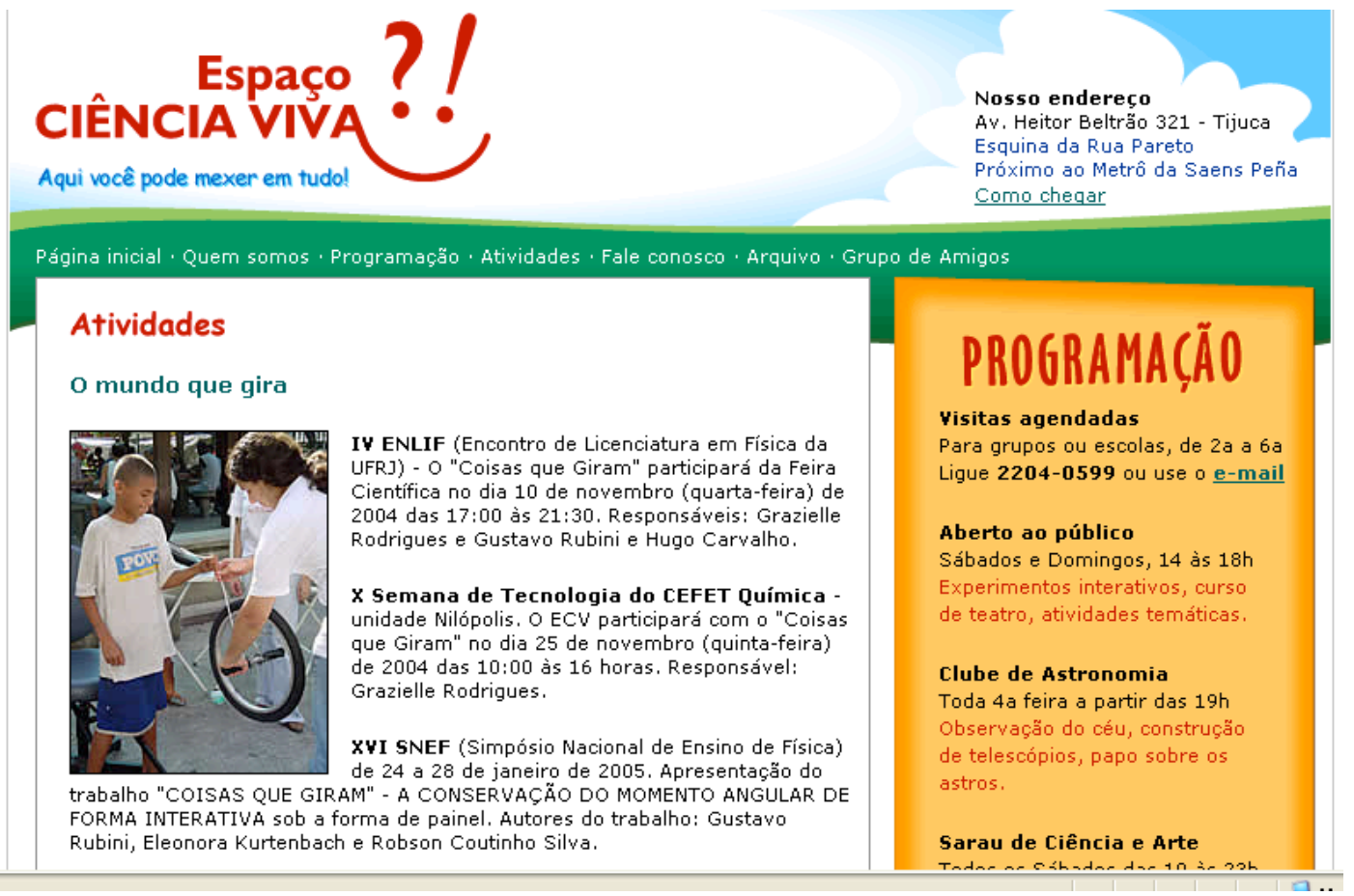

Figure 2. The Espaço Ciência Viva website as modified in September of 2004 


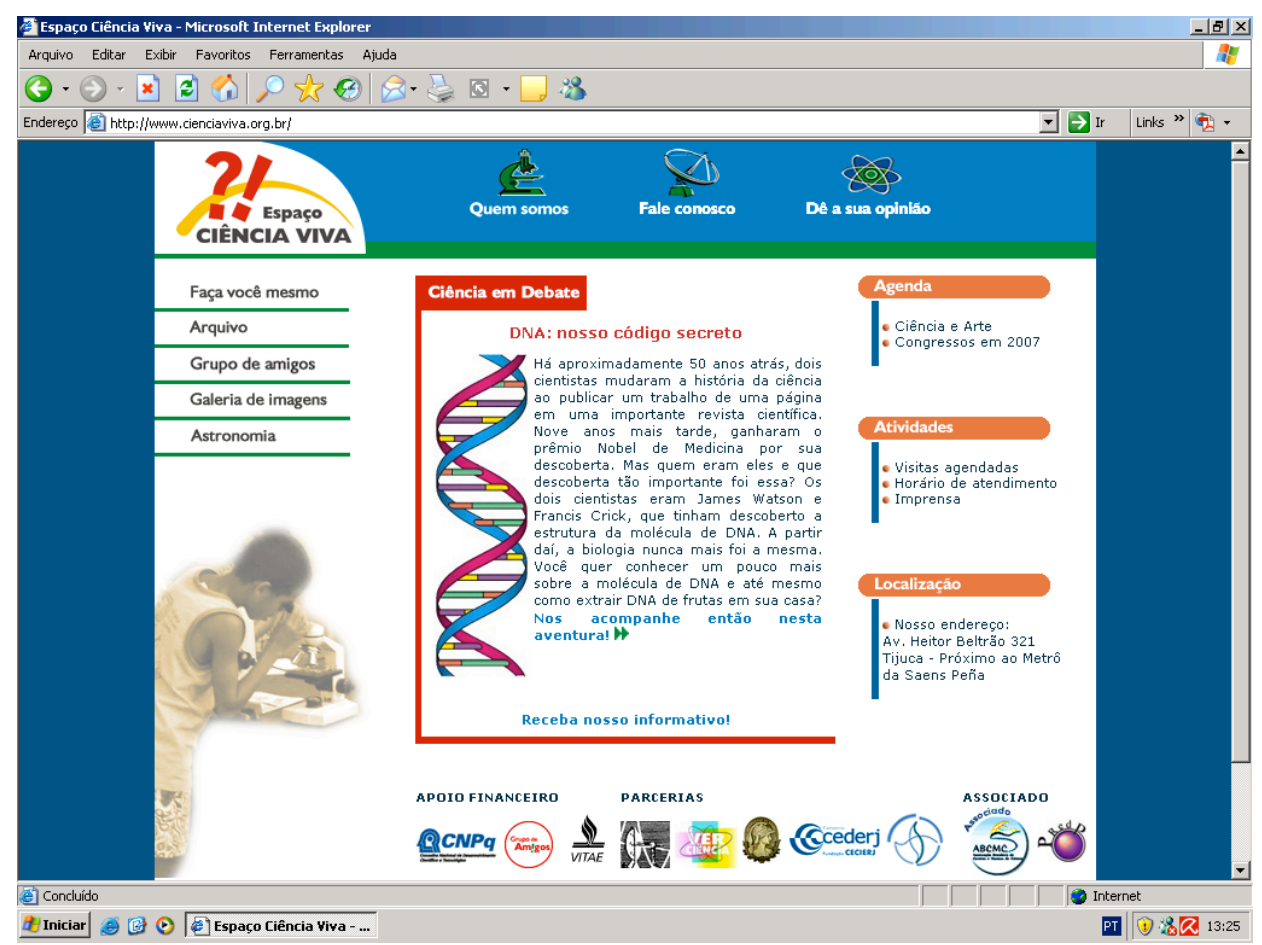

Figure 3. The Espaço Ciência Viva website as re-launched in December of 2005, containing the enumerated sections in Table 1 and the new graphic design. The editorial perspective began to prioritize exclusive scientific content, interviews with researchers and event coverage.

In April of 2006 an electronic informational bulletin (Figure 4) was introduced, being published biweekly on average and containing calls for events and releases of articles in the "Science in Debate" section. The bulletin has become one of the main means of communication of ECV activities. Since its introduction, the number of visits to the site has increased notably. The greatest number of visits generally occurs on the first three days after the bulletin is sent out. An increase of up to $50 \%$ in the number of accesses to the ECV site after the bulletin is sent out has been registered.

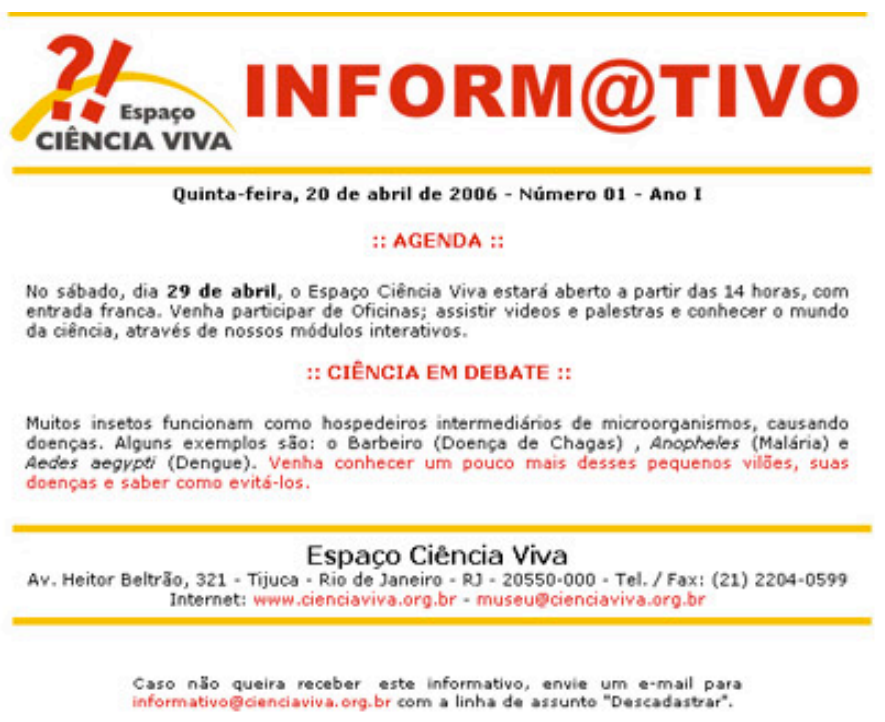

Figure 4. Espaço Ciência Viva Informational Bulletin, introduced in April of 2006. 
The most significant result of the remodeling of the Espaço Ciência Viva website was the increase in the number of visits, as shown in Figure 5. Comparing 2005, when the site only presented institutional information, to 2006 and 2007, years in which exclusive content and discussions on current scientific topics were included in the site, we observed a significant increase in the number of visits. Access to the site grew 200\% in 2006 and $615 \%$ in 2007, in comparison to 2005 (Figure 5). In the first semester of 2008 , the site reached $47 \%$ of the number of visits registered in the previous year and had already passed the total number of visits of 2006. We also observed that after launching the Ciencia Viva Virtual Project, we began to have more interaction with the public. This was reflected by the fact that the site was sought out a great deal through the "Give your opinion" channel, which is open to suggestions and questions about the most diverse scientific topics. In addition to this, requests to receive the informational bulletins from the ECV site are taken daily by the Ciência Viva Virtual staff.

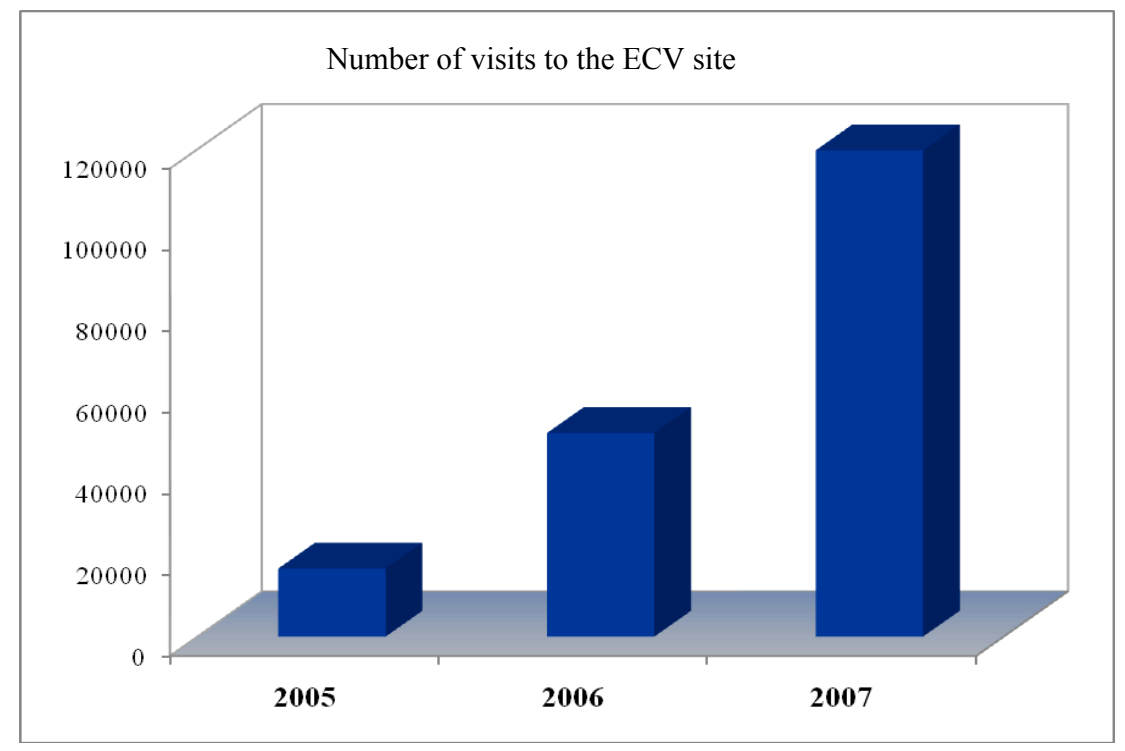

Figure 5. Number of visits to the Espaço Ciência Viva site from 2005 to 2007.

\section{Discussion}

On the Internet, everyone can access any and all information and all are also sources of news. However, upon thinking about this new communication space, we highlight both the potential that this means of communication offers, such as access to a large quantity of information, the immediate updating of documents, the integration of diverse forms of media, among others, and the problems that accompany these aspects, mainly in relation to the trustworthiness of the information sources. ${ }^{8}$ In addition to this, the complex and infinite fabric of the Web creates operational difficulties in selecting and editing the vast amount of material available. Taking all of these questions into consideration, what is the role of science institutions in the informational society? One of the roles is to serve as a compass for navigating in this sea of knowledge - in other words, to critically guide people, especially children and youth, in the search for information. In this way, the main objectives of the new Espaço Ciência Viva site are: (i) to be a trustworthy source of information; (ii) to be a space for the communication of scientific activities, debates, news, training, knowledge and art; (iii) to be an extension of the visit to the museum, without geographical barriers or time limits, thus making it possible for all to access information, experiments and debates; and (iv) to bring scientific knowledge closer to society by including science in daily concerns and interests. All of the efforts to remodel the ECV website were carried out in order to meet these needs, and the result of this work is seen in the astounding increase in the number of visits. In this 
way, the ECV site is a democratic space for the exchange of experiences. It has been able to reach an ever-broader public, mainly by presenting its visitors with exclusive, trustworthy, up-to-date material. In recent years, Brazilian science centers and museums in general - not just Espaço Ciência Viva - have begun to use technology, especially the Internet, more and more in order to reach a greater number of potential visitors and attain the main objective of spreading scientific knowledge. However, Brazilian science museum sites make use of an institutional editorial perspective. In other words, their web pages reflect their internal activities that are open to the public and their history in the context of science communication in Brazil. Ciência Viva Virtual opted to create exclusive scientific content as the main focus of its editorial perspective, connecting with the activities proposed at the real museum.

Although national science museum sites have gained greater visibility within Brazilian society, they are still isolated from science communication institutions on the world scene. The lack of content in Spanish and English is raised as one of the main reasons for lesser visibility of Brazilian and Latin American science sites in relation to the great centers of European and American science communication. ${ }^{9}$ Since the Internet gives us the possibility of circulating information without geographical barriers or time limits and allows an exchange of knowledge between different social and cultural groups, one of the challenges for Brazilian science center sites is to break the barrier of language, which has become the main factor that impedes connectivity between the world's science centers today. Overcoming this barrier, we will be ready to create and take part in a truly world wide web of science communication.

Translated by Robert Gartner

Notes and bibliography

${ }^{1}$ A.C. Teixeira, E.J.R. Brandão (2003), Internet e democratização do conhecimento: repensando o processo de exclusão social, Novas Tecnologias na Educação, 1(1)

${ }^{2}$ M. Gadotti (2000), Perspectivas atuais da educação, São Paulo em Perspectiva, 14(2), 1-11.

3 J. Larrosa, Pedagogia Profana - Danças, piruetas e mascaradas, $4^{\circ}$ edition, Ed. Autêntica (2003).

${ }^{4} \mathrm{~J}$. Wagensberg (2001), A favor del conocimiento científico (los nuevos museos), Endoxa: Series Filosóficas 14, 341-356.

${ }^{5}$ E.D. Marshall, A tecnologia para extensão da experiência dos Centros de Ciência, in Implantação de Centros e Museus de Ciência, Copyright, Programa de Apoio ao Desenvolvimento da Educação em Ciência, UFRJ, Rio de Janeiro (2002) 240-243.

${ }^{6}$ D.P. Cavalcanti, E.C. Bueno and C.C.B. Cavalcanti, Museu de Ciência Virtual: a homepage do Espaço Ciência Viva, Anais da X Reunión de la RED POP y IV Taller Ciencia, Comunicación y Sociedad, San José, Costa Rica, 2007. Available at: http://www.cientec.or.cr/pop/2007/BR-DanielleCavalcanti.pdf (Acesso em: Agosto 2008)

${ }^{7}$ L.F. Cazes, E.C. Bueno, D.P. Cavalcanti and C. Cavalcanti, Divulgação dos grandes temas científicos da atualidade através dos centros de ciência: ampliando o alcance popular, Anais da $59^{a}$ Reunião Anual da SBPC, 2007. Available at: http://www.servicos.sbpcnet.org.br/sbpc/59ra/senior/livroeletronico/resumos/R5738-1.html (Acesso em: Agosto 2008)

${ }^{8} \mathrm{M}$. Macedo, Revistas de divulgação científica: do texto ao hipertexto, in Ciência e público: caminhos da divulgação científica no Brasil, Copyright: Casa da Ciência - UFRJ (2002) 185-202.

${ }^{9}$ F.C. Gouveia and E. Kurtenbach, Mapping the web relations of science centres and museums from Latin America, Scientometrics, in press (2009).

\section{Authors}

Danielle Pereira Cavalcanti holds a PhD in Science from the Federal University of Rio de Janeiro (UFRJ). She does research in the area of Cellular Biology and Education in Science and Science Communication. She is a scientific consultant for the Espaço Ciência Viva site and coordinator of the project Ciência Viva e Sociedade: divulgando os grandes temas cientificos da atualidade, which is part of the Program to Stimulate Scientific and Technological Production and Communication (Fundação Carlos Chagas Filho de Amparo à Pesquisa do Estado do Rio de Janeiro/FAPERJ).

E-mail: dani.ufrj@gmail.com. 
Cecilia Carrossini Bezerra Cavalcanti is a doctoral student at the ECO/UFRJ School of Communication. She is a CNPq scholar and holds a Master's degree in Education, Diffusion and Administration in Biosciences from the Medical Biochemistry Institute of the Federal University of Rio de Janeiro (UFRJ). She does research in the area of Communication Technologies and Aesthetics and Science Communication. She is the editor-in-chief and architect of the information on the Espaço Ciência Viva site.E-mail: imprensa@cienciaviva.org.br.

How TO CITE: D.P. Cavalcanti, C.C.B. Cavalcanti, New languages for the spreading of scientific knowledge: broadening the dialog between science and society, Jcom 08(01) (2009) L01 